\title{
Swimming depths of offshore migrating longfin eels Anguilla dieffenbachii
}

\author{
Donald Jellyman $^{1, *}$, Katsumi Tsukamoto ${ }^{2}$ \\ ${ }^{1}$ National Institute of Water and Atmospheric Research, PO Box 8602, Christchurch, New Zealand \\ ${ }^{2}$ Ocean Research Institute, University of Tokyo, Minamidai, Nakano-ku, Tokyo 164-8639, Japan
}

\begin{abstract}
Pop-up tags were attached to 10 migratory female longfin eels Anguilla dieffenbachii, ranging in size from 6000 to $10550 \mathrm{~g}$. Tags were scheduled to ascend at monthly intervals, commencing 3 mo after release. A combination of eel mortality, tag failure, and premature detachment meant that limited data were retrieved. The 3 eels where tags remained attached for $25 \mathrm{~d}$ or more generally swam too deep for light reception and hence geolocation estimates, meaning that no tracks of their swimming routes could be determined; all 3 eels showed diel vertical movements with 1 fish always returning to near surface depths ( 1 to $10 \mathrm{~m}$ ), while the other 2 tended to ascend to $150-200 \mathrm{~m}$ but frequently dived to $>600 \mathrm{~m}$; maximum recorded depth was $980 \mathrm{~m}$. It was assumed that such extensive diel movement was in response to predator avoidance and also to thermoregulation as eels often spent time in 5 to $6^{\circ} \mathrm{C}$ water. The tag from one of these eels commenced transmissions at a location $700 \mathrm{~km}$ east of New Caledonia.This is the first evidence that this species moves to the tropics during spawning migrations.
\end{abstract}

KEY WORDS: Freshwater eel $\cdot$ Anguilla dieffenbachii $\cdot$ Swimming depth $\cdot$ Satellite

\section{INTRODUCTION}

The spawning ground of the endemic New Zealand longfin eel Anguilla dieffenbachii Gray is unknown. Although some larvae of the co-existing species $A$. australis Richardson have been collected (Jespersen 1942, Castle 1963, Aoyama et al. 1999), A. dieffenbachii is the only Anguilla spp. for which no larvae have been found (Jellyman 2003). The classical method of determining spawning areas of freshwater eels has been the collection of progressively smaller larvae (Schmidt 1922, Tsukamoto et al. 2002, McCleave 2003). With the advent of pop-up tags, there is the potential to track offshore migrating eels, and trials using 4 tagged eels were carried out by Jellyman \& Tsukamoto (2002), who tracked all 4 eels for 2 to 3 mo, by which time the eels had moved up to $1000 \mathrm{~km}$ off the east coast of the South Island of New Zealand. Based on the success of this earlier work, the present paper reports on the results of tagging a further 10 eels with pop-up tags.
Glass eels of Anguilla dieffenbachii are approximately 10 mo old upon arrival in New Zealand freshwaters (Marui et al. 2001). Based on a departure time of May-June for female longfins (Todd 1981), and a peak arrival time of longfin glass eels in September-October (Jellyman et al. 1999), we estimated a period of 5 to 6 mo for adult migration to the spawning ground, and for spawning. We therefore hypothesized that pop-up tags pre-programmed to ascend from migrating longfin eels after 6 to $7 \mathrm{mo}$ at sea might indicate the approximate location of spawning grounds for the species, while tags that ascended at shorter periods might confirm migration routes.

\section{MATERIALS AND METHODS}

As the methods used were generally similar to those described by Jellyman \& Tsukamoto (2002), they are only briefly outlined, although any differences are described in more detail. 
Eels. Approximately 30 migrating longfin females were caught in early May 2001 by commercial eel fishers, in Lake Ellesmere, South Island, New Zealand. Eels were retained in flowing fresh water and the 10 largest eels were tagged; these ranged in size from 1282 to $1445 \mathrm{~mm}$ (mean $1352 \mathrm{~mm}$, SE $19 \mathrm{~mm}$ ) and 6000 to $10550 \mathrm{~g}$ (mean $7800 \mathrm{~g}$, SE $42 \mathrm{~g}$ ). Differences in the tagging procedure from that used by Jellyman \& Tsukamoto (2002) were the use of heavier gauge monofilament nylon (45 kg breaking strain), and the inclusion of a small pressure-operated plunger (supplied by the tag manufacturers) on the nylon bridal immediately below the eye of the tag designed to cut the nylon if the tag reached depths of 1500 to $1800 \mathrm{~m}$. After tagging, eels were placed in aerated freshwater tanks, to which artificial sea salt was added in 5 equal amounts over a $20 \mathrm{~h}$ period; at the end of this time, salinity was $30 \%$ in each tank. For road transport to the sea, a distance of $7.5 \mathrm{~km}$, each eel was placed in a plastic bag contained within a polystyrene container $(1.2$ long $\times 0.5$ wide $\times 0.5 \mathrm{~m}$ deep) to which small quantities of the saline water had been added. Because air temperature was comparatively low $\left(8^{\circ} \mathrm{C}\right)$, and eels were inactive, they were not anaesthetized for this journey. At the release site, fresh seawater was added to the boxes $15 \mathrm{~min}$ before eels were released. Eels were released to the sea between 19:00 and 19:30 $\mathrm{h}$ on 24 May 2001; the sea conditions were calm, and individual eels were carried into water $0.5 \mathrm{~m}$ deep, and released on a receding wave.

Tags. The pop-up archival transmitting (PAT) tags (Wildlife Computers) used weighed $75 \mathrm{~g}$, were $175 \mathrm{~mm}$ (excluding the aerial) in length, and pressure tested to $1750 \mathrm{~m}$ depth. Of the 10 tags used, 2 were preprogrammed to ascend 3 mo after deployment, with 2 tags each subsequent month, to give a range of ascent times from 3 to 7 mo. Tags were programmed to record water temperature at hourly intervals (resolution $0.05^{\circ} \mathrm{C}$ ), depth $( \pm 0.5 \mathrm{~m})$ at hourly intervals (recorded as time-atdepth in 12 bins of prescribed depth intervals, e.g. Bin 1: >1 m, Bin 2: 1-9 m, Bin 3: 10-49 m, Bin 4: 50-99 m, Bins 5-11 were $100 \mathrm{~m}$ intervals from $100-199 \mathrm{~m}$ to 700-799 m, respectively, while Bin 12 was 800-1000 m). The tags use day length and times of sunrise and sunset to estimate latitude and longitude, respectively. The accuracy for latitude depends upon both latitude and time of year, and tag manufacturers state that best accuracy $\left( \pm 1^{\circ}\right)$ is at higher latitudes, and worst inaccuracies are near the equator and during equinoxes $\left( \pm 10^{\circ}\right)$. Manufacturers also claim that dawn and dusk light levels (wavelength $550 \mathrm{~nm}$ ) can be detected at depths of up to $300 \mathrm{~m}$ in clear water conditions. Upon ascension, the tags transmit data to ARGOS satellites for up to $3 \mathrm{wk}_{\text {; }}$ satellite fixes of pop off location are within $\pm 350 \mathrm{~m}$.

\section{RESULTS}

\section{Data received}

Not all tags could be deployed successfully. No transmissions were received from 3 tags, while continuous constant zero depth data indicated that 3 further tags had detached from the eels within a few days of deployment. A further tag (Tag 2) showed nearconstant depth and temperature from $7 \mathrm{~d}$ after release, and it was assumed that the eel had died and sunk to the bottom. Of the remaining 3 tags, depth data indicated that all had detached before the scheduled dates with attachment periods ranging from 26 to approximately $161 \mathrm{~d}$. For all these 3 tags, data series were dis-

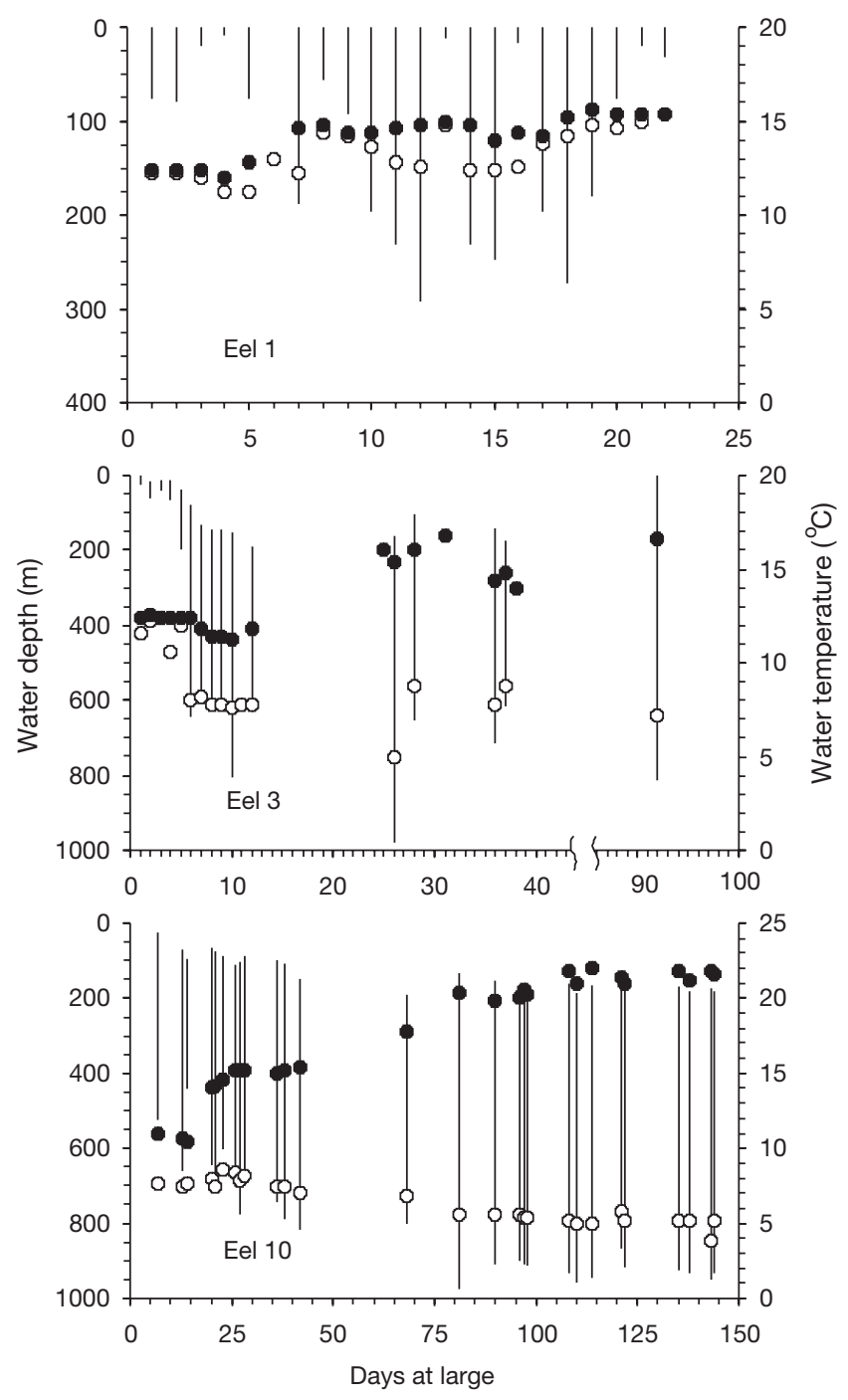

Fig. 1. Anguilla dieffenbachii. Minimum and maximum daily swimming depths (vertical lines), and minimum (O) and maximum (๑) temperatures recorded for 3 eels. Note that the horizontal scale for Eel 3 is not continuous 
continuous, and the proportion of potential data recovered ranged from $6.2 \%$ (temperature data, Tag 10) to $90.4 \%$ (temperature and depth data, Tag 1 ).

\section{Tag locations at first transmission}

Insufficient data were received from the 3 tags that remained attached for $>25 \mathrm{~d}$ to plot either positions on any given day or migration pathways. Reasons for this included sensor failure and the fact that eels often swam too deep for the tags to receive sufficient surface light to estimate latitude and longitude. The location at the point of first transmission of 2 tags (Tags 1 and 10) was determined; at the commencement of transmission (by which time it had been drifting at the surface for $66 \mathrm{~d})$, Tag 1 was at $38.505^{\circ} \mathrm{S}, 177.349^{\circ} \mathrm{W}$, approximately $1100 \mathrm{~km}$ northeast of the release point. A single transmission was received from Tag 3, and unfortunately this did not include a record of latitude. Tag 10 commenced transmissions approximately $700 \mathrm{~km}$ due east of New Caledonia $\left(21.847^{\circ} \mathrm{S}, 173.637^{\circ} \mathrm{E}\right), 2451 \mathrm{~km}$ from the release point (measured over a great circle). However, the depth record for this tag indicated that it prematurely detached from the eel $61 \mathrm{~d}$ before its scheduled release date.

In the absence of geolocation data, TOPEX/Poseidon satellite altimeter data (21 October to 22 December 2001) were used to compute surface geostrophic velocities to back-calculate a surface track that ended at the first location for Tag 10 during its 2 wk of surface transmissions. The method predicted that the tag could have ascended approximately $160 \mathrm{~km}$ northeast of New Caledonia, travelled southeast for $700 \mathrm{~km}$, before entering an anticlockwise eddy, where transmissions commenced on 22 December 2001.

\section{Swimming depth}

The depth records of the 3 tags indicated that while the eels differed in their preferred swimming depths, all 3 showed marked diel vertical movements. Eel 1 (= Tag 1) always swam in near-surface waters at some stage during the day, and often had a daily vertical movement of about $150 \mathrm{~m}$, but occasionally $250 \mathrm{~m}$ (Fig. 1), although almost $80 \%$ of the record was within $10 \mathrm{~m}$ of the surface (Fig. 2). Eel 3 swam in progressively deeper water until $6 \mathrm{~d}$ after release, after which it tended to range between 200 and 750 m (Fig. 1), with the maximum depth recorded being $980 \mathrm{~m}$. The high proportion of time that this eel spent in the 1 to $10 \mathrm{~m}$ depth zone (Fig. 2) is because most data were for the $10 \mathrm{~d}$ after release, and for the first 4 of these days, the eel did not descend below $60 \mathrm{~m}$.

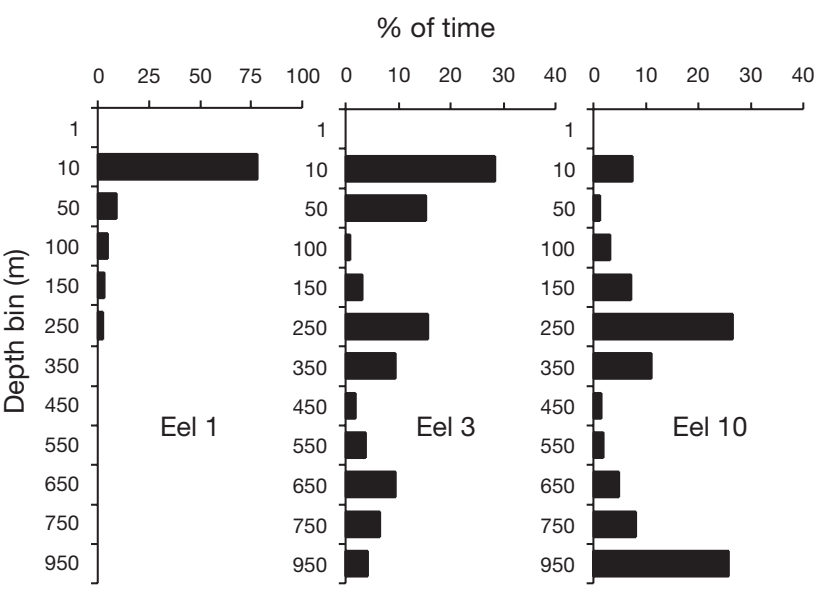

Fig. 2. Anguilla dieffenbachii. Percentage of time that 3 eels spent at various depths. Note that the intervals of the vertical scale are not regular, but in depth bins (e.g. $<1 \mathrm{~m}, 1-9 \mathrm{~m}$, $10-49 \mathrm{~m}$, etc.)

The swimming depth pattern for Eel 10 was rather similar to that of Eel 3, i.e. within 6 d of release, it established a diel pattern that normally showed an ascent to 150-250 m, and a decent to 800-900 m (Fig. 1); the maximum depth recorded was $976 \mathrm{~m}$. There was a tendency to swim to greater depths over time. In the absence of swimming tracks, estimates of swimming speed can only be very approximate. For Eel 10, if a pop-up location in the vicinity of $160 \mathrm{~km}$ northeast of New Caledonia is assumed, then arrival at this location by swimming in a straight line around a great circle $(2630 \mathrm{~km})$ would have meant an average swimming speed of $18.3 \mathrm{~km} \mathrm{~d}^{-1}$. Of course, as the eel was very unlikely to have swum in a direct line, the actual swimming speed would have been faster than this.

\section{Water temperature}

The limited temperature range experienced by Eel 1 (Fig. 1) reflects the relative lack of variation in depths swum by this eel. In contrast, Eels 3 and 10 frequently experienced daily temperature ranges of 8.0 and $16.0^{\circ} \mathrm{C}$ respectively (Fig. 1), with maximum daily ranges of 10.4 and $17.0^{\circ} \mathrm{C}$. For Eel 10, while minimum depth was relatively constant over time, maximum temperature increased progressively as a consequence of net northward movement towards the tropics. This eel also experienced relatively constant minimum temperatures of 5 to $6^{\circ} \mathrm{C}$.

\section{DISCUSSION}

The low rate of data recovery was particularly disappointing, as was the apparent premature detachment 
of a number of tags. Consequently, conclusions drawn from the results must be tentative, not only because of the few data received, but also because of the variation in swimming behaviour between eels.

The suggestion from previous tracking that migrating longfins moved well offshore to the east of the South Island before (presumably) migrating towards the tropics (Jellyman \& Tsukamoto 2002) could not be confirmed. The most significant outcomes from the present study were, firstly, knowledge that migrating eels frequently swam at considerable depths, sometimes to almost $1 \mathrm{~km}$, and the single eel whose tag remained attached for 5 mo swam to the tropics, an indication that spawning of longfins will occur in this general region. Of course, without collaborative information from other tags, the significance of this is uncertain as the eel might still have been en route to the spawning grounds rather than have arrived there. Because the eels usually swam too deep for reception of light, further studies of extensive oceanic migrations of eels may require correlation of recorded temperatures with oceanographic data, similar to those used by Takahashi et al. (2003) in a study of swordfish migrations.

\section{Swimming depth}

The 4 longfins tracked in a previous trial of pop-up tags (Jellyman \& Tsukamoto 2002) appeared to swim within the photic zone, approximately $200 \mathrm{~m}$; some diel vertical movement was inferred from temperature records (as tags did not have depth recorders). Although occasional records show tagged Anguilla anguilla diving to depths of $700 \mathrm{~m}$ (Tesch 1989), most studies have indicated that eels seldom venture below $300 \mathrm{~m}$ for sustained periods (e.g. Tesch 1978, 1989, Fricke \& Kaese 1995, Kuo et al. 1996). The frequent swimming at depths of 800 to $900 \mathrm{~m}$ by Eel 10 in the present study is therefore considerably deeper than would have been predicted from previous knowledge. Based on experimental observations and theoretical calculations, Tesch (1995) and Tesch \& Rohlf (2003) proposed that the maximum diving depth should be about $600 \mathrm{~m}$, again considerably less than that observed in the present study. Robins et al. (1979) identified an eel they photographed at $2000 \mathrm{~m}$ near the Bahamas as Anguilla spp., although this observation has 'yet to be critically evaluated' (Tesch 2003). Ignoring this latter record, swimming depth records from the present study are the deepest authenticated records for any Anguilla spp. to date.

Although no geolocations were available for any of the eels, assuming they swam directly offshore at the mean swimming speeds 15 to $31 \mathrm{~km} \mathrm{~d}^{-1}$ taken from the previous study (Jellyman \& Tsukamoto 2002), they would encounter depths $>1000 \mathrm{~m}$ within 3.5 to $7.5 \mathrm{~d}$. From the depth tracks of the 3 eels (Eels 1, 3, and 10), it likely that within a few days of release they would not be diving deep enough to reach the sea bed, meaning they were almost always swimming in open waters. That migrating silver eels may spend some time on the bottom is evidenced by their occasional capture in bottom trawls (e.g. Todd 1973), the fact that they are found in the stomachs of predatory benthic fish (Reinsch 1968), and from tracking studies over the continental shelf (e.g. Tesch 1989).

All 3 eels for which swimming depth data were available showed a consistent diel pattern of a vertical migration. Because of the method of data storage, it was not possible to determine whether this was a classical pattern of descending at dawn and ascending at dusk, or the reverse, as both patterns have been observed in migrating silver eels (Tesch 1989, McCleave \& Arnold 1999). Vertical diel migrations were noted from previous pop-up tagged longfins (Jellyman \& Tsukamoto 2002), although here too it was not possible to determine the timing of such migrations; given that 'classical' vertical movement has been recorded more frequently (e.g. Tesch 1978, 1989, Westerberg 1979, Tesch et al. 1991, McCleave \& Arnold 1999) than reverse movement (Stasko \& Rommel 1974, Tesch 1978, McCleave \& Arnold 1999), it is assumed that the present data represent a dawn descent, and a dusk ascent. Again, because of the method of data storage, it was not possible to determine whether there was a single descent and ascent per day; while such a pattern would be consistent with continuous temperature tracks from Jellyman \& Tsukamoto (2002), tagged eels have sometimes showed several daily excursions (e.g. Tesch 1995), although this may have been a result of tagging affecting their behaviour (Tesch 2003).

So, why would silver eels undergoing a migration of several thousand kilometres during which they do not feed invest energy in diel movements? While silver eels at sea usually dive during the day to avoid light (Tesch et al. 1992), in the present study, eels often swam to depths well beyond the level of perceptible light penetration, i.e. depths of 200 to $300 \mathrm{~m}$. There could be several explanations for such deep dives followed by ascents, including predator avoidance, thermoregulation, the need to obtain cues for migration, movement to specific depths to obtain current-assisted transport, or some combination of these. These will be considered in turn.

\section{Predator avoidance}

The only records of predation on silver eels by openwater marine species are of silver eels remains from 
swordfish Xiphias gladius stomachs (Grassi \& Calandruccio 1897, in Tesch 2003), and an eel found in the stomach of a sperm whale Physeter macroephalus caught near the Azores (Vaillant 1896).

Swordfish make frequent deep dives, deeper during the day than the night, probably in response to vertical movements of prey (Takahashi et al. 2003), and have been recorded to depths over $600 \mathrm{~m}$ (Carey \& Robison 1981), and approximated from temperature records to depths of $900 \mathrm{~m}$ (Takahashi et al. 2003). In contrast, marlin Makaira spp. seldom venture below the thermocline (e.g. Holland et al. 1990, Block et al. 1992, Pepperell \& Davis 1999) and hence usually remain within the top 100 to $200 \mathrm{~m}$, meaning they would be much less likely to encounter silver eels than would swordfish.

Both blue sharks Prionace glauca and mako sharks Isurus oxyrinchus are common in the South Pacific (Francis et al. 2001). Both species make frequent vertical dives to $400 \mathrm{~m}$ (Carey \& Scharold 1990), although blue sharks have been recorded to $600 \mathrm{~m}$. Sperm whales Physeter macroephalus and pilot whales Globicephaia spp. frequently dive to depths $>1000 \mathrm{~m}$ (Watkins et al. 2002) and $600 \mathrm{~m}$ (Baird et al. 2002), respectively. Therefore, swordfish, some sharks and toothed whales are all capable of predating on migrating silver eels, and diel vertical movement by eels to avoid encountering such predators is a distinct possibility.

\section{Thermoregulation}

While descending the water column may be a response to predator avoidance, eels may ascend the water column to encounter warmer water. Tuna may show reverse thermoregulatory movements (descending as deep as $1000 \mathrm{~m}$ to cool off as their internal body temperature is several degrees warmer than surrounding seawater, Block et al. 2001), but species like blue sharks (Carey \& Scharold 1990) and swordfish (Carey \& Robison 1981) are thought to ascend into warmer waters to regain heat lost at depth. Daily vertical ascents to warmer waters may also assist rates of digestion in billfish and tuna (e.g. Takahashi et al. 2003), but this is irrelevant for silver eels as they do not feed during their oceanic migrations.

Eel 10 frequently encountered minimum temperatures from 5 to $6^{\circ} \mathrm{C}$, similar to the temperature range predicted by Jellyman $(1991,1997)$ at which activity ceases for eels in fresh water. The near-constancy of this temperature (Fig. 1) may indicate that lower temperatures, more than increased depth, limits the depth of vertical movements. Vollestad et al. (1986) regarded $4^{\circ} \mathrm{C}$ as the lower limit for commencement of silver eel migrations, a temperature similar to that considered by Tesch (2003) as providing the limit to vertical diving. A daily ascent to within $300 \mathrm{~m}$ of the surface resulted in this eel experiencing maximum temperatures ranging from 14.0 to $21.8^{\circ} \mathrm{C}$. Thus, daily vertical movements to encounter warmer water are also a possibility, and are consistent with the observation of Tesch et al. (1991) that silver eels in the Baltic Sea preferred to swim above the thermocline, rather than encounter the cooler water below it.

\section{Navigation cues}

Celestial cues are known to be important for navigation of species of insects and birds (e.g. Gauthreaux 1980) but were considered by Tesch $(1974,1989)$ to be unimportant for eels. During their oceanic migration, silver eels are considered to be more sensitive to light than to temperature (Tesch 1978, Tesch et al. 1992), and daytime descents are considered to be for reasons of light avoidance. In the present study, the assumed nocturnal ascent was usually to depths too great (100 to $200 \mathrm{~m}$ ) for surface light to have been detectable, again confirming Tesch's (1974) hypothesis that nightlight is unimportant for eel navigation at sea. The primary directional cues for silver eels in the open sea are considered to be geomagnetic ( e.g. Tesch 1974, Tesch et al. 1992), but there is no evidence that geomagnetism varies with depth, and hence no reason for eels to adjust their swimming depth on a diel basis.

\section{Favourable currents}

Within tidally influenced areas of the sea, silver eels are known to use selective tidal transport (Parker \& McCleave 1997, McCleave \& Arnold 1999) to assist movement, presumably to help conserve energy. While there would be considerable energetic benefits by swimming in currents flowing in the desired direction of travel of the eels, in New Zealand, favourable currents that flow to the north are the deep water boundary currents. These currents are found at depths of several thousand metres (Carter et al. 1998), too deep to have been encountered by eels in the present study.

So, maybe the answer to diel movement is a combination of predator avoidance and thermoregulation. If swimming at considerable depth is an effective means of avoiding predators that are primarily visual feeders, then why not stay at these depths continuously? Probably, to do so would result in excessive lowering of body temperature, meaning that eels ascend the water column to warmer temperatures during the evening, when there is a reduced likelihood of being eaten by predators. 
Acknowledgements. We acknowledge the assistance of NIWA staff, J. Sykes (field assistance), B. Fredric (programming the tags and data retrieval), and S. Chiswell (modeling of surface drift). Thanks also to Clem Smith and Malcolm Wards for providing eels, and to T. and N. Gould for making their factory facilities available. Thanks also to the Te Waihora Eel Management Committee and the Ministry of Fisheries for respectively approving the project and allowing fishers access to areas normally closed to eel fishing. G. Oon of Argos, Australia, was also very helpful with the procedures for downloading satellite information, while the staff of Wildlife Computers, especially D. Dau, provided prompt answers to many questions. R. McDowall of NIWA provided helpful comments on the manuscript. Finally, we wish to thank the University of Tokyo for providing funds for the study.

\section{LITERATURE CITED}

Aoyama J, Mochioka N, Otake T, Ishikawa S, Kawakami Y, Castle P, Nishida M, Tsukamoto K (1999) Distribution and dispersal of anguillid leptocephali in the western Pacific Ocean revealed by molecular analysis. Mar Ecol Prog Ser 188:193-200

Baird RW, Borsani JF, Hanson MB, Tyack PL (2002) Diving and night-time behavior of long-finned pilot whales in the Ligurian Sea. Mar Ecol Prog Ser 237:301-305

Block BA, Booth DT, Carey FG (1992) Depth and temperature of the blue marlin, Makaira nigricans, observed by acoustic telemetry. Mar Biol 114:175-183

Block BA, Dewar H, Blackwell SB, Williams $\mathrm{T}$ and 5 others (2001) Archival and pop-up satellite tagging of Atlantic bluefin tuna. In: Sibert JR, Nielsen JL (eds) Electronic tagging and tracking in marine fisheries. Kluwer Academic Publishers, Dordrecht

Carey FG, Robison BH (1981) Daily patterns in the activities of swordfish, Xiphias gladius, observed by acoustic telemetry. Fish Bull 79:277-292

Carey FG, Scharold JV (1990) movements of blue sharks (Prionace glauca) in depth and course. Mar Biol 106:329-342

Carter L, Garlick RD, Sutton P, Chiswell S, Oien NA, Stanton BR (1998) Ocean Circulation New Zealand. NIWA Chart Misc Ser No. 76, NIWA, Wellington

Castle PHJ (1963) Anguillid leptocephali in the southwest Pacific. Zool Vict Uni Wellington 33:1-14

Francis MP, Griggs LH, Baird SJ (2001) Pelagic shark bycatch in the New Zealand longline fishery. Mar Freshw Res 52: 165-178

Fricke H, Kaese R (1995) Tracking of artificially matured eels (Anguilla anguilla) in the Sargasso Sea and the problem of the eel's spawning site. Naturwissenschaften 82: $32-36$

Gauthreaux SA (1980) Animal migration, orientation and navigation. Academic Press, New York

Holland K, Brill R, Chang RKC (1990) Horizontal and vertical movements of Pacific blue marlin captured and released using sportfishing gear. Fish Bull 88:397-402

Jellyman DJ (1991) Factors affecting the activity of 2 species of eel (Anguilla spp.) in a small New Zealand lake. J Fish Biol 39:7-14

Jellyman DJ (1997) Variability in growth rates of freshwater eels (Anguilla spp.) in New Zealand. Ecol Freshw Fish 6: 108-115

Jellyman DJ (2003) The distribution and biology of the South Pacific species of Anguilla. In: Aida K, Tsukamoto K, Yamauchi K (eds) Eel biology. Springer, Tokyo, p 275-292
Jellyman D, Tsukamoto K (2002) First use of archival transmitters to track migrating freshwater eels Anguilla dieffenbachii at sea. Mar Ecol Prog Ser 233:207-215

Jellyman DJ, Chisnall BL, Bonnett ML, Sykes JRE (1999) Seasonal arrival patterns of juvenile freshwater eels (Anguilla spp.) in New Zealand. NZ J Mar Freshw Res 33: 249-262

Jespersen P (1942) Indo-Pacific leptocephalids of the genus Anguilla. Dana Rep 22:1-128

Kuo CL, Nakamura A, Tsukamoto K, Suzuki K, Liao IC (1996) Tracking of Japanese eel Anguilla japonica by ultrasonic transmitter in the southwestern waters of Taiwan. J Fish Soc Taiwan 23:279-287

Marui M, Arai T, Miller MJ, Jellyman DJ, Tsukamoto K (2001) Comparison between the early life histories of New Zealand temperate eels and Pacific tropical eels revealed by otolith microstructure and microchemistry. Mar Ecol Prog Ser 213:273-284

McCleave JD (2003) Spawning areas of the Atlantic eels. In: Aida K, Tsukamoto K, Yamauchi K (eds) Eel biology. Springer, Tokyo, p 141-155

McCleave JD, Arnold GP (1999) Movements of yellow- and silver-phase European eels (Anguilla anguilla L.) tracked in the western North Sea. ICES J Mar Sci 56:510-536

Parker SJ, McCleave JD (1997) Selective tidal stream transport by American eels during homing movements and estuarine migration. J Mar Biol Assoc UK 77:707-725

Pepperell JG, Davis TLO (1999) Post-release behaviour of black marlin, Makaira indica, caught off the Great Barrier Reef with sportfishing gear. Mar Biol 135:369-380

Reinsch HH (1968) Fund von Fluss-Aalen Anguilla anguilla (L.) im Nordatlantik. Arch FischWiss 19:62-63

Robins CR, Cohen DM, Robins CH (1979) The eels, Anguilla and Histiobranchus, photographed on the floor of the deep Atlantic in the Bahamas. Bull Mar Sci 29:401-405

Schmidt J (1922) The breeding places of the eel. Phil Trans R Soc B Biol Sci 211:179-208

Stasko AB, Rommel SAJ (1974) Swimming depth of adult American eels (Anguilla rostrata) in a saltwater bay as determined by ultrasonic tracking. J Fish Res Board Can 31:1148-1150

Takahashi M, Okamura H, Yokawa K, Okazaki M (2003) Swimming behaviour and migration of a swordfish recorded by an archival tag. Mar Freshw Res 54:527-534

Tesch FW (1974) Speed and direction of silver and yellow eels, Anguilla anguilla, released and tracked in the open North Sea. Ber Dtsch Wiss Komm Meeresforsch 23: 181-197

Tesch FW (1978) Telemetric observations on the spawning migration of the eel (Anguilla anguilla) west of the European continental shelf. Environ Biol Fish 3:203-209

Tesch FW (1989) Changes in swimming depth and direction of silver eels (Anguilla anguilla L.) from the continental shelf to the deep sea. Aquat Living Resour 2:9-20

Tesch FW (1995) Vertical movements of migrating silver eels (Anguilla anguilla) in the sea. Bull Sea Fish Inst 2: $24-30$

Tesch FW (2003) The eel. Blackwell Science, Oxford

Tesch FW, Rohlf N (2003) Migration from continental waters to the spawning grounds. In: Aida K, Tsukamoto $\mathrm{K}$, Yamauchi K (eds) Eel biology. Springer, Tokyo, p 223-234

Tesch FW, Westerberg H, Karlsson L (1991) Tracking studies on migrating silver eels in the Central Baltic. Meeresforschung 33:183-196

Tesch FW, Wendt T, Karlsson L (1992) Influence of geomagnetism on the activity and orientation of the eel, Anguilla 
anguilla (L.), as evident from laboratory experiments. Ecol Freshw Fish 1:52-60

Todd PR (1973) First record of the freshwater eel Anguilla dieffenbachii Gray to be caught at sea. J Fish Biol 5: 231-232

Todd PR (1981) Timing and periodicity of migrating New Zealand freshwater eels (Anguilla spp.). NZ J Mar Freshw Res 15:225-235

Tsukamoto K, Aoyama J, Miller MJ (2002) Migration, speciation, and the evolution of diadromy in anguillid eels. Can J Fish Aquat Sci 59:1989-1998

Vaillant L (1896) Sur la présence de l'anguille commune

Editorial responsibility: Otto Kinne (Editor-in-Chief),

Oldendorf/Luhe, Germany en haute mer. C R Hebd Séances Acad Sci 126:1429-1430

Vollestad LA, Jonsson B, Hvidsten NA, Naesje TF, Haraldstad O, Ruud-Hansen J (1986) Environmental factors regulating the seaward migration of European silver eels (Anguilla anguilla). Can J Fish Aquat Sci 43:1909-1916

Watkins WA, Daher MA, DiMarzio NA, Samuels A, Wartzok D, Fristrup K, Howey PW, Maiefski RR (2002) Sperm whale dives tracked by radio tag telemetry. Mar Mamm Sci 18:55-68

Westerberg H (1979) Counter-current orientation in the migration of the European eel. Rapp P-V Reun Cons Int Explor Mer 174:134-143

Submitted: February 5, 2004; Accepted: September 28, 2004 Proofs received from author(s): January 21, 2005 